$S B$

994

$\mathrm{STC}_{22}$

UC-NRLF

|||||| || || ||| || ||| |||||||||||

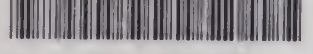

\$B $70 \quad 735$

$\infty$
0
0
$\infty$ 

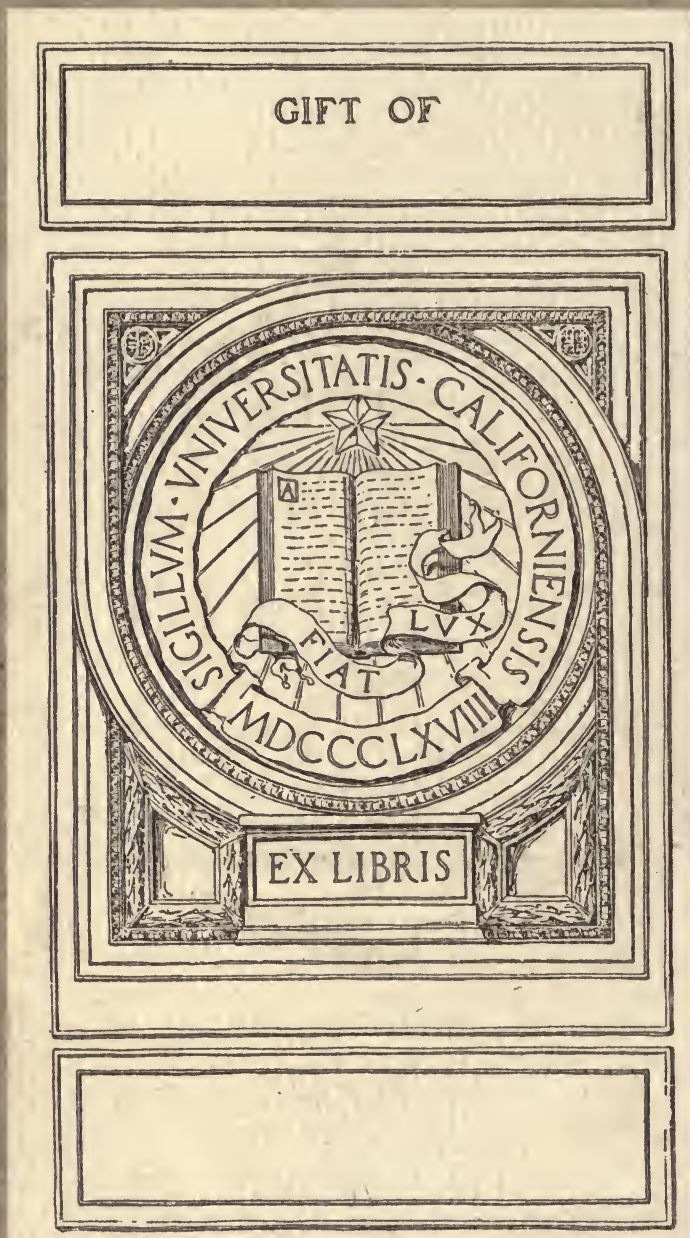


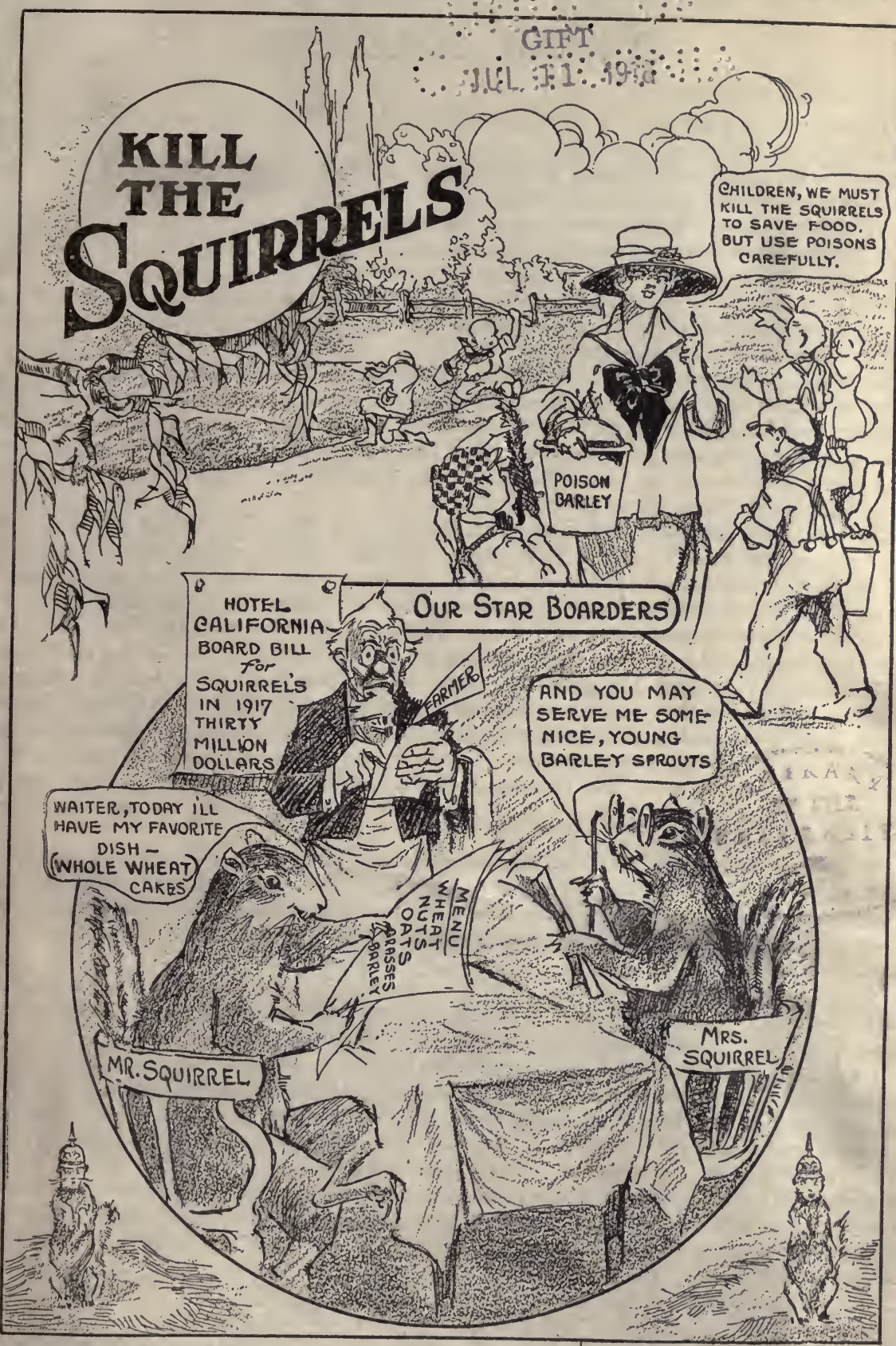




\section{SCHOOL SOLDIERS.}

DEAR BOYS AND GirLs:

Is there one of your number who would like to be a member of a company made up of American boys and girls fighting to protect your big brother or cousin at the front in Europe? We have enemies here at home more destructive, perhaps, than some of the enemies our boys are fighting in the trenches.

Food for the soldiers, will prove one of the greatest factors in winning the war. Our ally friends are so busy fighting and their land is so torn with shells that many of them can not work and produce stuff to eat as they did before the war; so you can see how vitally important it is we should see to it that our rich acres in this country produce the food not only to feed our soldiers, but to feed the boys and girls and grown-ups in Europe who can not farm while the war lasts.

Have you ever noticed the work of the ground squirrel? Probably you know that he destroys a great deal of grain and does no good to the war nor the world. Our federal government has found from making very ciuse investigation that the squirrels in California destroy about thirty million dollars' worth of fovistuffs each year. Some of this is grain that would make bread for our soldiers and some is alfalfa and food for stock that would. make beef to feed these boys.

Now we must not allow this destruction to continue. We are not loyal to our government and its interests if we fail to perform our part in the conservation of food, which L:eans saving every bit of it we possibly can. 'Think of it! 'Thirty million dollars' wortl of food lost in our beloved California means fifty-five dollars' worth for each of the five hundred forty-one thousand and sixty-five $(541,065)$ school children in the state. The way this is estimated is by dividing thirty million by 541,065 , which gives $\$ 55$ for each child.

Now you can see how it is your duty to try to stop this loss. After you have thought this over and realize that you can do your part the same as a soldier in uniform in helping Uncle Sam, I am sure you will begin at once to organize a company of soldiers in your class or in your school, march them out where the squirrel army is eating the food that should go to your brothers and cousins, and win your battle in the war we are making against the destruction of food. You can do this so easily if you will just say to yourself that you will.

This little leaflet tells you just how to go about it to poison the squirrels and what methods to use. Your County Horticultural Commissioner also will gladly tell you more about it because he is interested in this great battle for Uncle Sam. Remember that every squirrel you destroy means that you have saved more than one dollar's worth of food during the year of 1918.

I will leave it to you to answer whether or not this is a good work for boys and girls to do to help their government. As soon as you have organized consult your school teacher, superintendent, county horticultural commissioner or farm adviser.

I am going to help you too, and so that you will do your very best I will give a prize of $\$ 50.00$ to the grammar school whose pupils kill the most squirrels; $\$ 30.00$ for the next greatest number and $\$ 20.00$ for the third largest. I will give the same prizes to the high school whose pupils kill the first, second and third largest numbers. Your teachers will tell you more about the prizes and help you win one of them.

Remember that poisoned grain is dangerous to handle and be careful in using it. Place it carefully so that your pets, or other domestic animals, will not be poisoned. It probably will be best to secure your grain from the county horticultural commissioner or farm adviser.

Let us make these "squirrel-less" days.

Always at your service for the protection of our glorious state.

G. H. HECKE,

State Commissioner of Horticulture. 


\section{CALIFORNIA STATE COMMISSION OF HORTICULTURE. Forum Building, Sacramento, Cal. RODENT CONTROL DIVISION.}

\section{U. S. BIOLOGICAL SURVEY FORMULA.}

DIRECTIONS FOR PREPARING POISON TO KILL CALIFORNIA, OR "DIGGER" GROUND SQUIRRELS.

Barley, recleaned grain

Strychnin (powdered alkaloid)

Bicarbonate of soda (baking soda)

Saccharin

Heavy corn sirup

Thin starch paste

Glycerin

16 quarts
1 ounce
1 ounce
$1 / 10$ ounce
$\frac{1}{4}$ pint
$\frac{3}{4}$ pint
ablespoonful

In a clean vessel mix thoroughly 1 ounce of powdered strychnin (alkaloid), 1 ounce of common baking soda, and 1/10 ounce of saccharin. Crush all lumps of the soda with mixing spoon. To this add $\frac{1}{4}$ pint of heavy corn sirup and stir thoroughly to a smooth creamy paste free from lumps. Over this pour $\frac{3}{4}$ pint of thin hot starch paste and stir well. (The starch paste is made by dissolving 1 heaping tablespoonful of dry gloss starch in a little cold water which is then added to $\frac{3}{4}$ pint of boiling water. Boil and stir constantly until a clear thin paste is formed.) Add the tablespoonful of glycerin and stir thoroughly, making sure that none of the heavy sirup paste still sticks to the bottom of the container. Pour this mixture over 16 quarts of good cleaned barley and mix well so that each grain is coated.

For mixing small quantities an ordinary galvanized wash tub is convenient. For larger quantities a tight smooth box may be used, and the mixing may be done with a spade.

Each quart of the poisoned grain is sufficient for 40 to 50 baits. This quantity SCATTERED along squirrel trails, or on clean, hard places on the surface about the holes, will not endanger stock.

N. B.- Strychnin in any form other than the powdered strychnin alkaloid is not effective in the above formula.

\section{CAUTION.}

All poison containers and all uncleaned utensils used in the preparation of poisons should be kept PLAINLY LABELED and OUT OF REACH of irresponsible persons ind live stock, and children should be cautioned in the use of poisoned barley.

N. B.-For Oregon ground squirrels or "picket pins" use 16 quarts of oats instead of whole barley.-W. C. J.

\section{CALIFORNIA “DIGGER” GROUND SQUIRREL.}

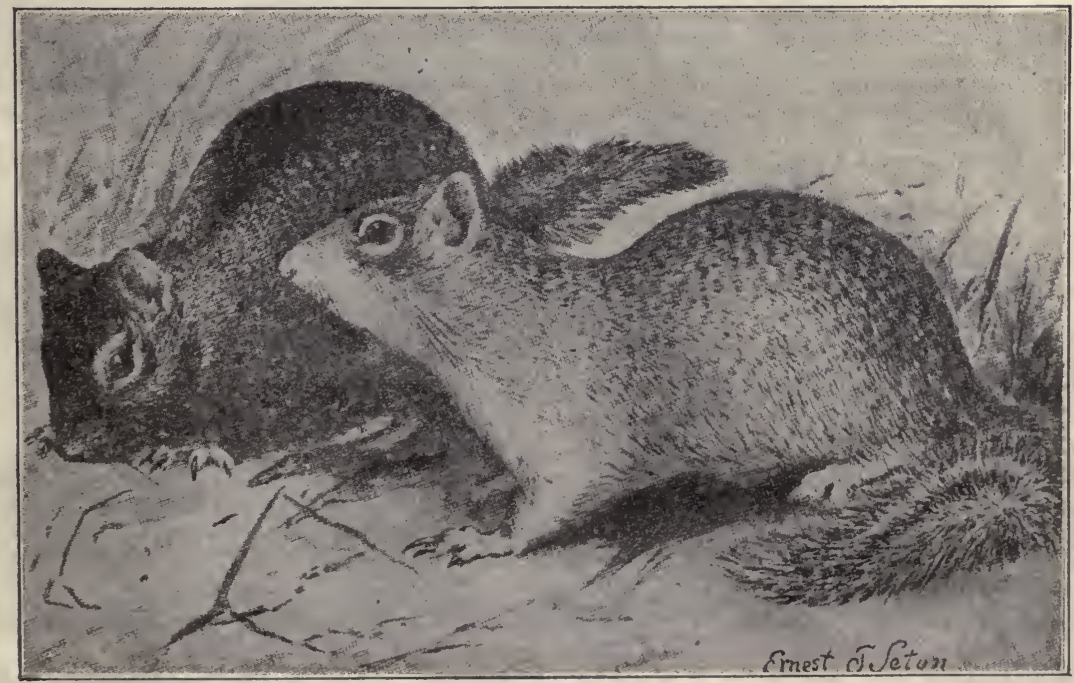

Courtesy Biological Survey, U. S. Dept. Agr.

The "digger" ground squirrel is found most widely distributed over California and in a large measure assisted in destroying $\$ 30,000,000$ worth of food products last year. 
THE CALIFORNIA “DIGGER" SQUIRREL.

By W. C. JAcobsen, Supt. Rodent Control.Division, State Commission of Horticulture.

California is well known for the many trees, flowers, birds and mammals that are found alone within her borders. An animal of great economic importance is found almost just so, that being the California Digger ground squirrel of which there are three species ranging from well into Oregon, south into Mexico.

They are found all over California (excepting the desert areas) at elevations ranging from sea level up to 8,000 feet in the high Sierras. In this state the ground squirrel inhabits the hills and valleys of the Coast Range, our big valleys and the sparsely timbered slopes of our mountains. Because of his wide distribution, great numbers, and ability to live under practically all conditions, he can inflict severe damage in a very short time.

However, his old habits have led to a movement that definitely spells his doom. This great destroyer of food now has the law after him. He must be taken dead or alive whereever found. He will be shown no quarter, no chance to live.

\section{Habits and Life History.}

The many burrows with trails radiating from them are usually places marking the home of a squirrel family. The burrow extends several feet into the ground, having some where along its course a comfortable nest lined with soft grass and straw.

The young are born from the first of February until the end of April, depending upon the locality, those in the south being born earlier, and in the north later in the season. The number of young varies from 4 to 12 , averaging about 8 . Where there is a continual abundant supply of food, the number of young occasionally reaches 15 .

An important point, wherein the squirrel differs from most of the smaller rodents, is his habit of working in the day time, for he has a much better chance to get food then, than an animal whase time is largely spent in the dark. In addition, he usually works the year around. In Modoc and Lassen counties, in the plains area, the Oregon ground squirrel is common and does much damage. Its dormant period is approximately from July 31 to February 15. Often in the dryer regions squirrels will go into a dormant state because of food or water scarcity. Certain ground squirrels can live their whole lives without water, obtaining moisture only from the food eaten.

\section{Food Destroyed.}

The foods most commonly taken are grain, fruits, green herbage, vegetables, nuts and the seeds of range, forage and cultivated plants. Wild seeds are abandoned for the more tasty ones, such as wheat, barley and oats, of which the squirrel often carries in his cheek pouches from 350 to 500 kernels at one time.

During the spring, or green period, the herbage of growing plants is taken.

\section{Range of Feeding.}

The squirrel will start to take grain as soon as seeded in the ground, then the green shoots, growing stalks, green grain heads, ripe heads, grain waiting to be harvested, and from the sacks or granary. Likewise on fruit, the squirrel chews the bark of young trees, eats the green buds, green fruit, ripe fruit and dried fruit from drying trays.

He will eat worms, young poultry and occasionally eggs. Numerous quail eggs in the mountain sections are destroyed by squirrels each year.

With their systematic plan of destroying these crops, it is easy to understand how untold damage can be done in a short time, and the damage he does has placed the ground squirrel in disfavor by every one. We all are his enemies.

We have learned that there is at least one ground squirrel per acre in California. If this be so and each destroyed only one cent's worth of food in two weeks, they will destroy $\$ 30,000,000$ worth of crops in a year, for there are over $100,000,000$ acres in our state. Many are the instances where they do hundreds of dollars damage in one day by breaking irrigation levees, washing out railways and roadways. They also carry fleas which may spread a dreaded disease known as bubonic plague. In the oil fields of California they do great damage by causing leaks in the great storage tanks.

We surely can find some way to destroy the squirrel and the boys and girls can do their part. There are many methods, and for a few cents we can kill this rodent which in a grain field or orchard may cost us in damage from $\$ 2.00$ to $\$ 5.00$ each.

\section{Natural Enemies.}

We should never forget that these rodents have natural enemies. Hawks, owls and snakes kill great hordes each year. Still, many of us unknowingly destroy some of these animals, which truly are our best friends. Of snakes, there is a single poisonous one in California - the rattler. Nearly every eagle, hawk and owl is busily engaged capturing and eating small rodents. Only occasionally do they steal poultry. The weasel and badger, even after many years of trapping and shooting, help a great deal in the control of squirrels, and house cats do good in this line.

\section{Methods of Control.}

Trapping.

No. O Newhouse.

Guillotine rat trap, large size.

Sclf-setting traps.

Shooting.

Air rifles.

.22 rifles.

Drowning.

Flooding, with aid of dog.

\section{Poisons.}

Baits and strychnin on fruit, vegetables and melons, in dry season.

Poisoned grain.

Poisonous gases or suffocating cases.

After all. we need the combined effort of everyone to reduce the enormous damage done by squirrels.

A squirrel in time saves killing nine. 


\section{당 \\ PROCLAMATION}

Executive Departiment, State of California

The State Commissioner of Horticulture has instituted a campaign to destroy the ground squirrel throughout the State. It is said that these rodents do an annual damage to the amount of $\$ 30,000,000$, a great part of this damage consisting in the destruction of foodstuffs, and in these times special efforts should be made to prevent such loss.

In connection with the campaign the State Commissioner of Horticulture has personally offered prizes to those schools of all classes which make the best record in killing squirrels. I heartily endorse the plan, and I hope that the efforts of those in charge of the campaign will be crowned with success, and in connection therewith I do hereby set aside the week of April 29th to May 4th as Ground Squirrel Week, and trust that during that time the school children and all other persons will do their utmost to relieve the country of the ground squirrel pest.

\section{William D. STEPHENS}

Governor

Dated: Sacramento, April 8, I9r8.

\section{HERBERT HOOVER, UNITED STATES FOOD ADMINISTRATOR, ENDORSES SQUIRREL CONTROL CAMPAIGN}

Washington, D. C., April 9, 1918

GEO. H. HECKE,

\section{Commissioner of Horticulture,} Sacramento, Cal.

Understand you are undertaking campaign for the eradication of ground squirrels in California. This has my hearty approval as these squirrels destroy vast quantities of food which might otherwise be used for support of our armies abroad and the allies. The school children should be of great assistance in this campaign and the knowledge that they are doing a patriotic duty should stimulate them to their utmost efforts.

HERBERT HOOVER
TMENT

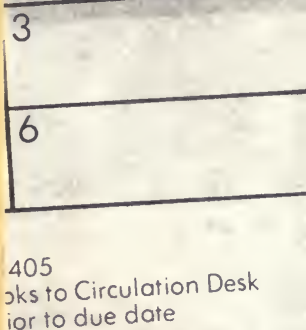

ELOW

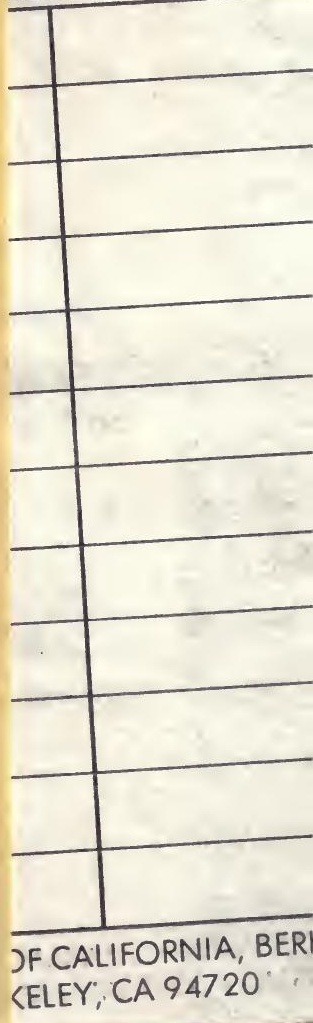


THE CALIFOF

By W. C. JAcobsen, Supt. Rodent Cc

California is well known for the found alone within her borders. An a, just so, that being the California Dig? ranging from well into Oregon, south

They are found all over California from sea level up to 8,000 feet in th inhabits the hills and valleys of the timbered slopes of our mountains. Bec ability to live under practically all ce short time.

However, his old habits have led to great destroyer of food now has the law ever found. He will be shown no quar

Habits :

The many burrows with trails radi: home of a squirrel family. The burrc some where along its course a comfortal

The young are born from the first of the locality, those in the south being bo The number of young varies from 4 to 1 : abundant supply of food, the number of $\mathrm{y}$

An important point, wherein the squi his habit of working in the day time, for than an animal whose time is largely spen year around. In Modoc and Lassen coun rel is common and does much damage. It to February 15. Often in the dryer regiol of food or water scarcity. Certain grous water, obtaining moisture only from the $f$

\section{Food}

The foods most commonly taken are gr: the seeds of range, forage and cultivated $p$ tasty ones, such as wheat, barley and oa cheek pouches from 350 to 500 kernels at

During the spring, or green period, the

Range o

The squirrel will start to take grain as shoots, growing stalks, green grain heads, $r$ from the sacks or granary. Likewise on fru eats the green buds, green fruit, ripe fru

He will eat worms, young poultry and $o c$ mountain sections are destroyed by squirre.

With their systematic plan of destroyin untold damage can be done in a short time, a squirrel in disfavor by every one. We all are

We have learned that there is at least . If this be so and each destroyed only one $c_{1}$ destroy $\$ 30,000,000$ worth of crops in a year, state. Many are the instances where they dc breaking irrigation levees, washing out railn which may spread a dreaded disease known a fornia they do great damage by causing leak:

We surely can find some way to destroy the part. There are many methods, and for a fer grain field or orchard may cost us in damage $f_{3}$

Natural Eı

We should never forget that these rodents snakes kill great hordes each year. Still, man animals, which truly are our best friends. Of California - the rattler. Nearly every eagle, $h$ and eating small rodents. Only occasionally badger, even after many years of trapping and of squirrels, and house cats do good in this line.

Trapping.

No. O Newhouse.

Guillotine rat trap, large size.

Self-setting traps.

Shooting.

Air rifles.

.22 rifles.

Methods of $\mathrm{C}$

Drowning.

Flooding, with aid of dog. 
RETURN CIRCULATION DEPARTMENT

TO $\rightarrow 202$ Main Library

LOAN PERIOD 1 . 2

HOME USE

4

5

\section{3}

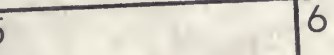

ALL BOOKS MAY BE RECALL

1 -month loans may be recharged by bringing books to Circulation Desk

6-month laans may be rechay be made 4 days prior to due date

Renewals and recharges may be mod

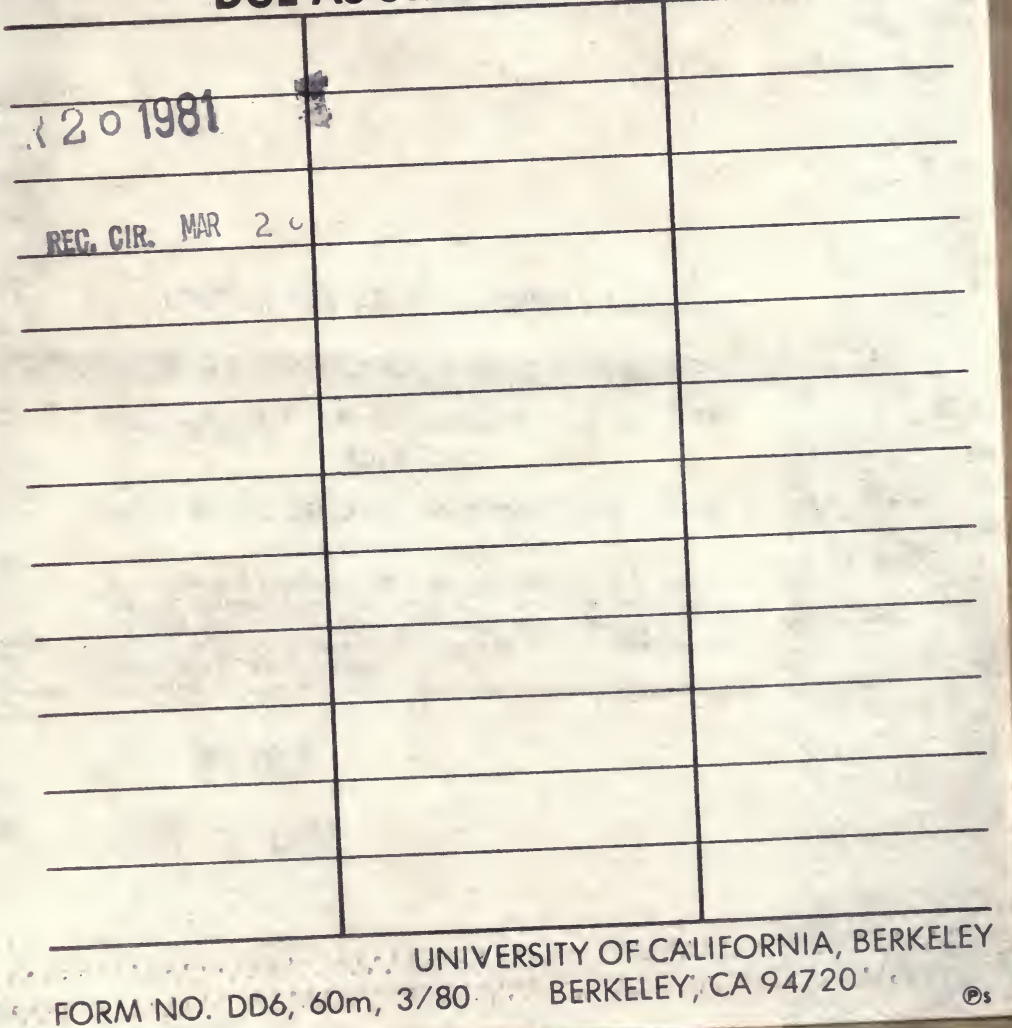




\section{ative 0}

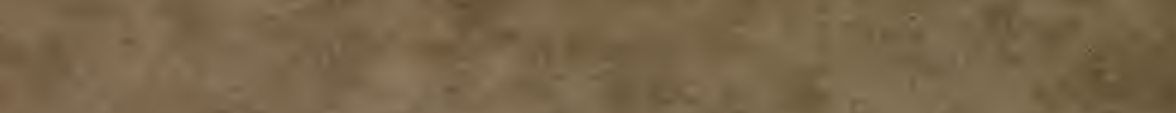

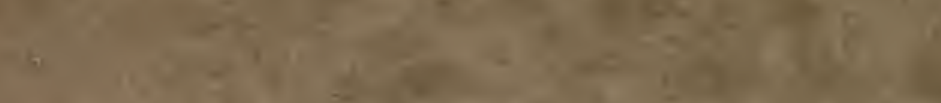

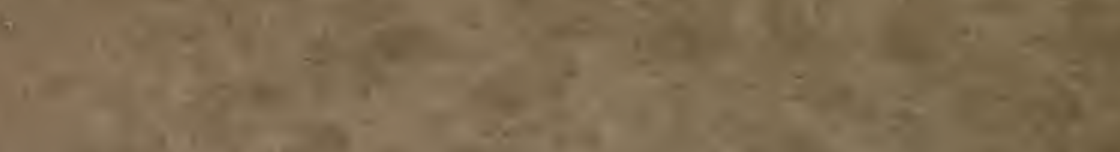

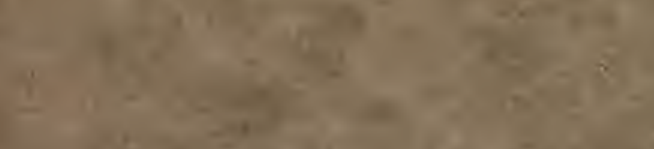

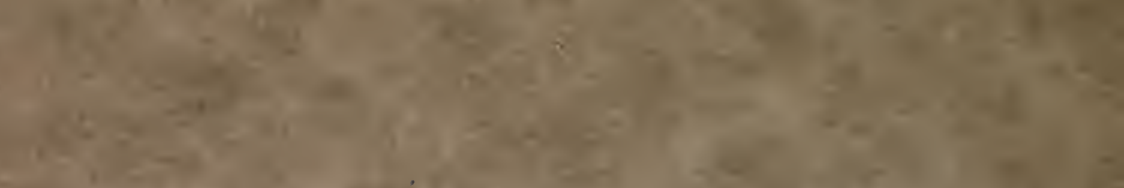

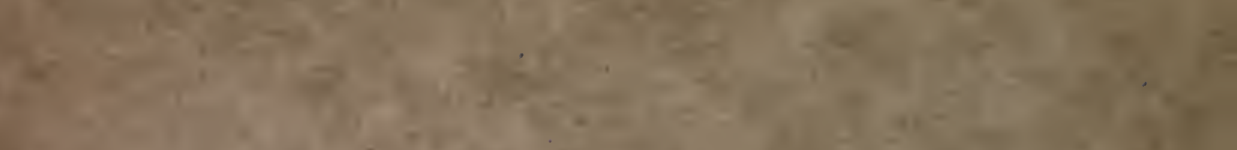

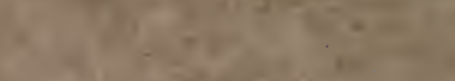
(3)

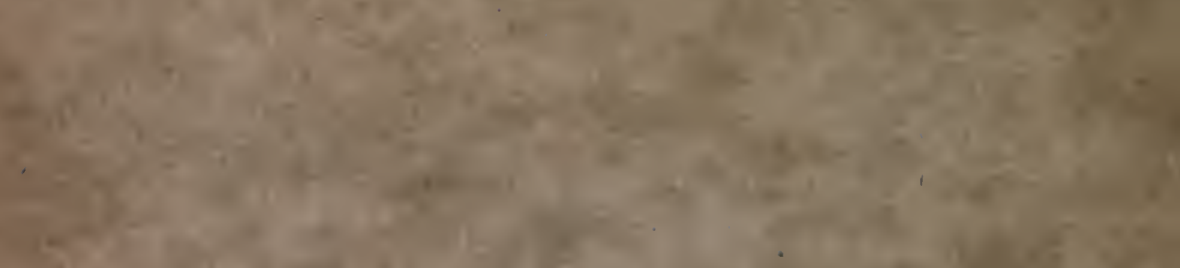

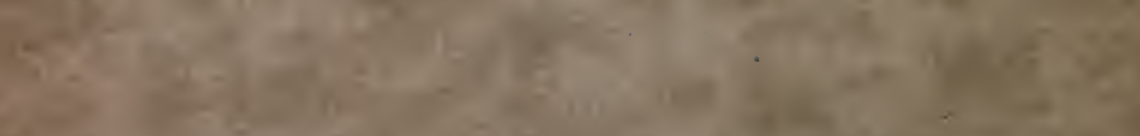

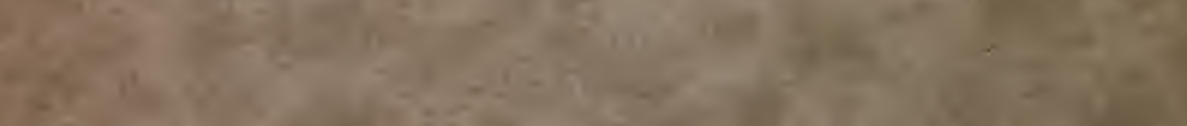

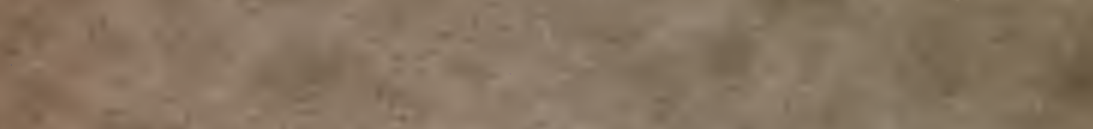

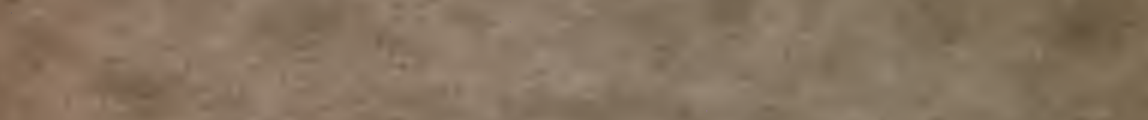

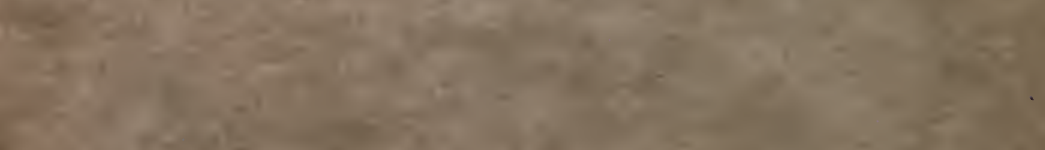

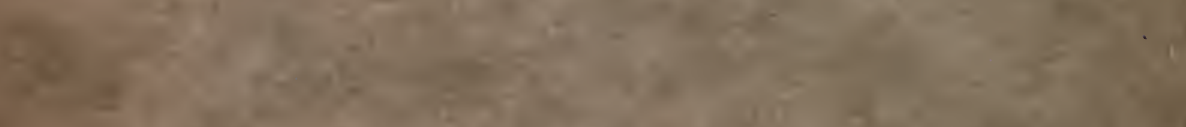

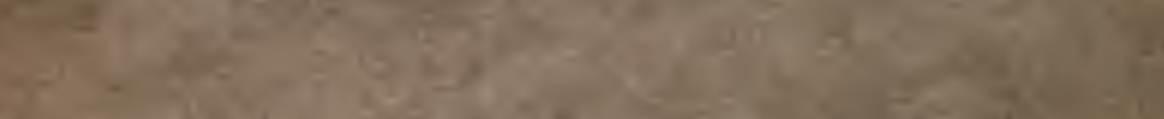

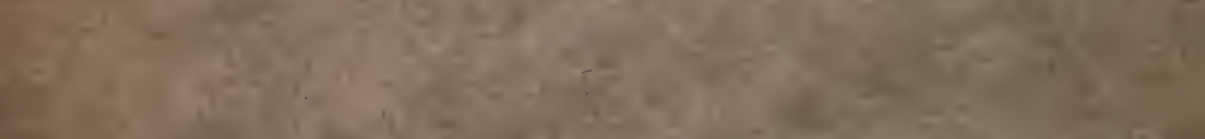

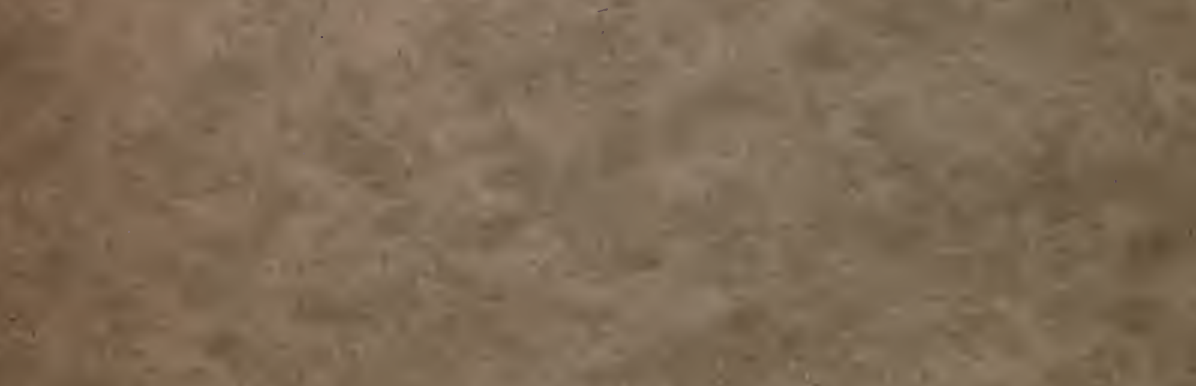

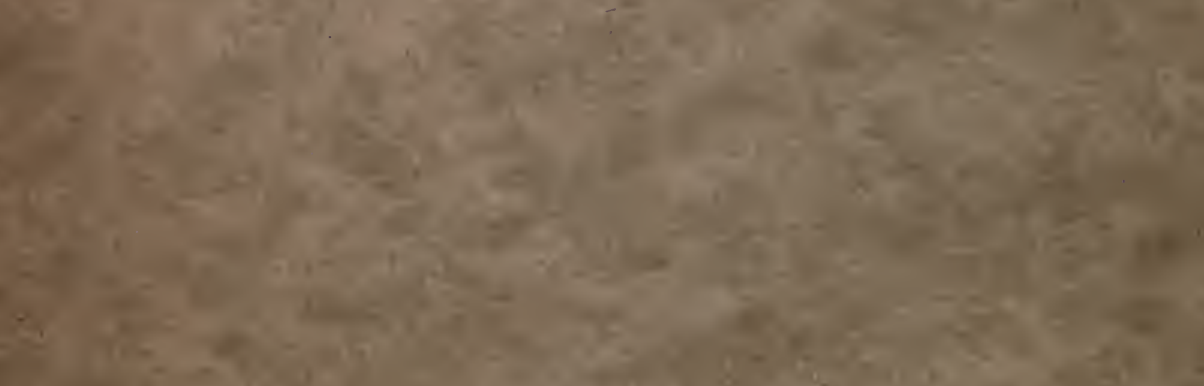

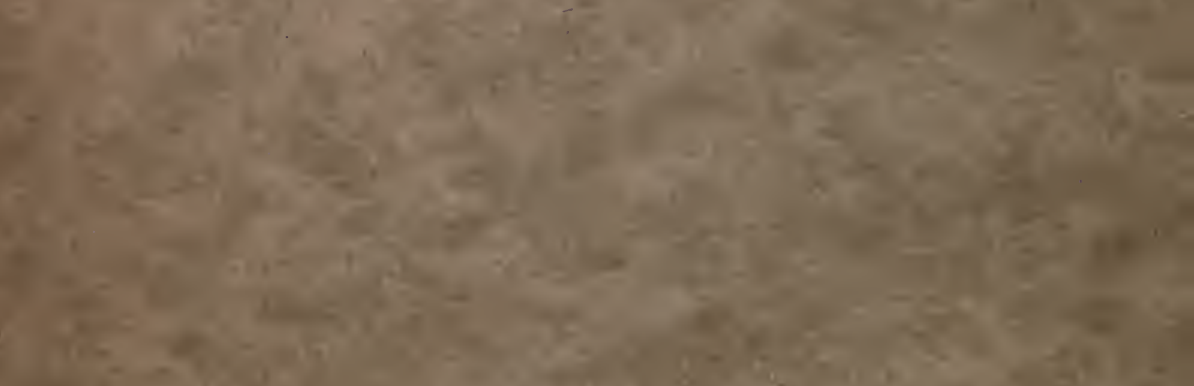

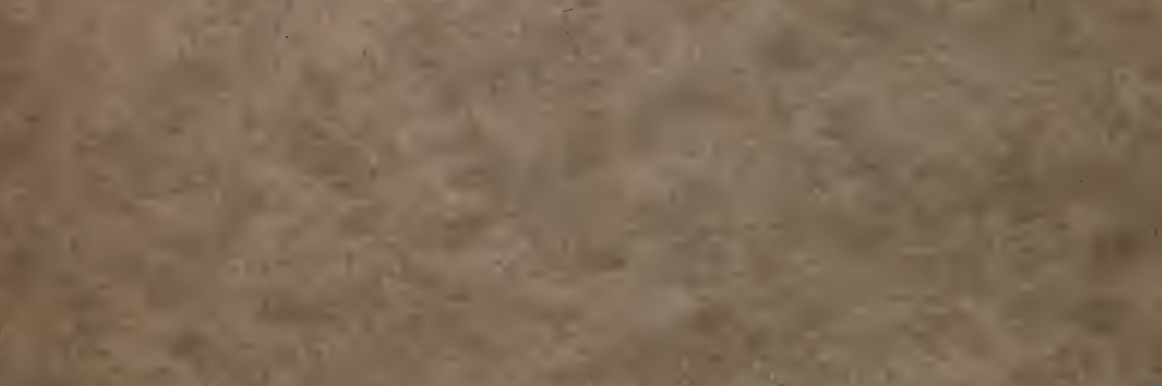

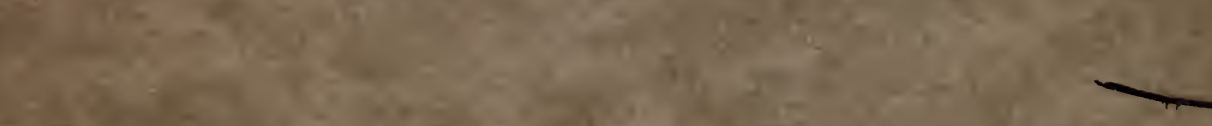

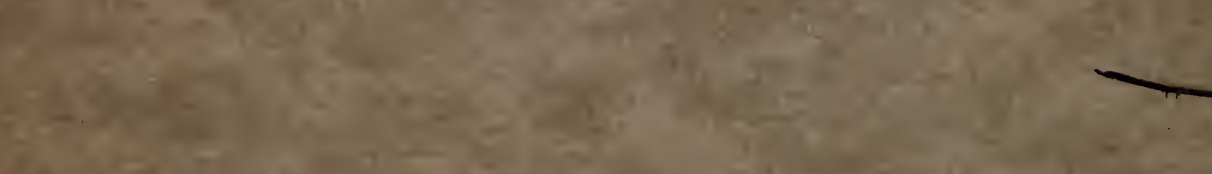

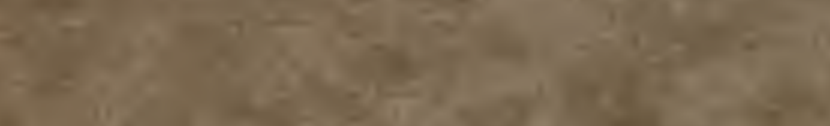
8 $=-1$.

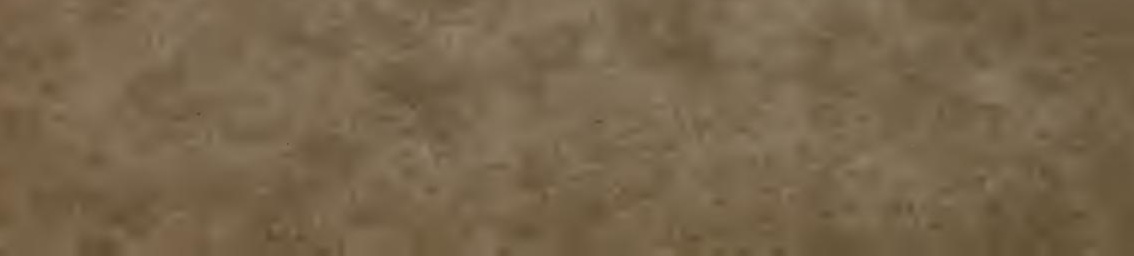

